\title{
Overview of Environmental Jurisprudence within Environmental Ethics
}

\author{
Kemi Anthony Emina \\ Department of Religious Studies and Philosophy, \\ Delta State University, Abraka, Delta State, Nigeria. \\ Email: eminakemi@yahoo.com
}

\begin{abstract}
Environmental Jurisprudence's highest achievement is its codification of a change in ethics, and a legal recognition that both individual and governmental agency responsibility extend to the natural world. This article provides an overview of Environmental Jurisprudence as it relates to environmental ethics. It examines both the foundation of Environmental Jurisprudence as well as the concept of human rights. The article also critically discusses international environmental law from the perspective of human rights. This research concludes by arguing that despite the attempt made in the international regime for adding eco-centric values in environmental law, environmental jurisprudence to date has continued with anthropocentric ideas with all concerns for safeguarding the means of human survival.
\end{abstract}

Keywords: Environmental jurisprudence; Environmental ethics; human rights; environmental rights.

\section{INTRODUCTION}

The discourse of environmental law-making bears several and diverse ethical obligations to be encompassed. The term environment itself is loosely understood to comprise of all variety of biotic and a biotic components which includes soil, water, plants, animals and collectively the land and the survival of each component is inter- linked and inter-dependent on the each other's existence (Ogar \& Bassey 2019). A pertinent set of examples of interdependencies is such as emission of greenhouse gases resulting from the host of human activities cause climate change which in turn causes a rise in the sea level, excessive rain, flooding in some regions and extreme drought in other cases.

A good environment provides a good and healthy life for all who form the part and parcel of the environment (Mendie \& Eyo 2016; Njar \& Enagu 2019; Eyo 2019; Duke 2020). Thus the notion of environmental ethics ought to pervade political decision making pursuing human interest for maximization of production and consumption at the cost of other species of the planet (Akpan \& Leonard 2018). However, unchallenged claims of human beings of being superior above all species and epistemic concern made them use nature in accordance with their own convenience owing to which nature has been ruthlessly tortured, and consequently shattered and destroyed (Faye 2016). In the era when constant progress in technological development started, human actions had been harsh to nature's interest as maximization of economic benefit had been the priority. Even the urge of having environmental regulations through the means of law-making is guided by economic interest. For example, the fact that 


\section{4| Jurnal Office: Jurnal Pemikiran Ilmiah dan Pendidikan Administrasi Perkantoran \\ Vol. 6, No. 1, January-June 2020, Page 53-70}

tropic rainforests provide inputs for medicinal products appreciated across the globe has been the only reason for calls to protect forests.

Economic incentives have driven to foster global trade by extracting, for example, oil, coal, natural gas, or by technologically modifying agricultural products to genetically modified organisms. The generation, transportation and use of these products have caused serious harm to the environment. As a consequence, nature's action has been brutal, whimsical and selfdestructive. Manipulations with the nature with a crave to achieve economic goals have been and continue to be costly to human beings. After many irreparable damages have been caused human beings understood that if such brutality to nature continues for the sake of pursuing their narrow self- interests, in coming future not only the survival of other species of the planet be at stake but also their very existence may be at question (Bassey 2019).

Nature itself is very complex, as its actions are beyond the power of human resistance. Thus time came for them to rethink their ruthless barbarity against nature and inculcate ideas based on values and ethics that promulgate environmental protection. Environmental values that might underpin environmental law by far understood, have strived to balance economic efficacy and human preferences which involve complex precepts of human self-interest and economic incentives though they aim to legitimize human interest with an agenda of attempting to adjust social and economic priorities by reconciling environmental protection objectives and economic growth. Therefore, in an era, while human rights ideas started evolving in the international platform, those ideas were conjoined with the values of environmental protection. The theoretical background of international environmental law has vastly developed to recognize objectives that ultimately strive to produce better conditions of life on earth. This is the major reason why this research would be looking at the subject matter of Environmental Ethics in Environmental Jurisprudence.

\section{The Foundation of Environmental Jurisprudence}

The foundation of environmental jurisprudence however was first asserted with the claim of universal concern for human rights which seeks to preserve, conserve and restore the environment for ensuring descent right to life to human beings. Environmental law intertwined with the human rights aspect is argued to enhance the protection of environment with the aid of human rights machineries established both at global and local levels (Burger 2013). The reason for the same may be best understood by analyzing the objectives of the environmental law and human rights law separately. There is also a need to analyse international law step by step in order to understand for whose better interest environment was considered to have been protected in various stages of development.

At the very initial stage, the concept of human rights attached to environment was understood to be human right to environment, where human beings shall have uncontrolled or unrestricted right to utilize the resources of the nature (United Kingdom Environmental Law Association 2014). In the second stage of development, arose the concern to restore natural resources for the future generations of human race who can also have the equitable share of the resources like their ancestors (Menell 2019). In the third stage, when the exploitation of the 
natural resources has inadvertently resulted brought in the question of sustenance of the planet earth, human beings strived to realize the intrinsic value that is the nature's worth and transcended to recognize the value of the same independent of human interests (Menell 2019). This journey of development in the international realm involved a myriad of complexity. The complexity lied in their formulations and ethical obligations which they had to encompass. But, interestingly what we find is, in none of the stages of development, we do give up the previous rationale on the basis of which environmental law ought to be framed.

Thus, in the final development recognized so far, that is understanding environmental law based on ecocentric perspective where we recognize the value of every natural component, does not actually evade the idea that human beings shall pursue their interests to safeguard their present and future generations. The thesis therefore ought to analyse the different instruments which were born out of different environmental ethical considerations at different points of time. The methodology of understanding the environmental law rationales in the light of ethics is termed as -deep level enquiry.

In the present context, the environmental law involves one or more than one ethical perspective. These perspectives may be anthropocentric or non- anthropocentric. When we term, environmental law to be anthropocentric, we generally link it up with human rights morals. Human rights which are understood to be inalienable to every human being has got its recognition after several years of struggle. Human rights were therefore perceived to the most sentient of all rights, and thus seek to protect for the benefit of humankind both on a local and global scale. Human rights have centred on fundamental aspirations of human beings with much more developed compliance mechanisms allowing individuals and groups to claim their rights. The inclusion of an environmental dimension in the human rights regime had become necessary in view of the recognition of the pervasive influence of local and global environmental conditions upon the recognition and realization of human rights. In legal terms, the linkages ought to have enhanced the protection in both fields as the protection of the environment would benefit from the established machinery whereas the human rights system would be enhanced by the inclusion of new interpretative elements until recently ignored.

\section{Development of the Concept of Human Rights}

The period of struggle till the nineteenth century against autocratic kingship brought about revolutions and developed various themes and concepts for establishing the definition of human rights. A new basis was created for the individualistic and liberalistic understanding of society that found expression in the American Declaration of Independence and in the French Revolution. The idea of liberal democracy drew its origin from its ancient roots of natural law theories, which spoke of natural rights (Ikegbu et al. 2013). This established the concept of rule of law where States were obligated to ensure rights to humans and such rights could only be abrogated by effective means of law. As stated by St. Thomas Aquinas, a propagator of Natural Law theory, law is -nothing else than an ordinance of reason for the common good, made by him who has care of the community and promulgated (Coyle 2017: 76). Therefore, to him, the operation of law needs to be dictated by reasons to realize human ends. Thus all laws are part of 


\section{6| Jurnal Office: Jurnal Pemikiran Ilmiah dan Pendidikan Administrasi Perkantoran \\ Vol. 6, No. 1, January-June 2020, Page 53-70}

a comprehensive, articulated system which must be promulgated in accordance with some rule of reason.

The function of law comes with general legal mission of making men good and to restrain the wicked from their acts of tyranny. Therefore, the concept of law lays the foundation of the concept of rights, rights in the sense that of specific rights to choose and change their rulers in the realization of common good for human well-being. Rights ensure guarantees that are attached to particular individuals who can invoke them (Coyle 2017). They offer high priority; the compliance with them is mandatory rather than discretionary. As a response to this growing awareness, the late nineteenth century witnessed new philosophies to be ushering in the form of human rights to address the ultimate aim to be derived at. Human Rights, in a rhetoric sense, were realized to be certain legal entitlements which are by nature, inherent, inalienable and universal to human beings (Coyle 2017). Chief amongst these rights are those to life, liberty and property. These rights were conferred to them owing to the fact that they were born as human beings and not because they were subjected to state governance.

However, these human rights concept did of course have some adverse bearing with the legal theories of utilitarianism and positivism which had gained predominance at that point of time. According to Bentham, the father of utilitarian theory, the natural law theory is a -rhetoric non-sense and is to be subjected to -anarchical fallacies. To him, natural or moral rights, suffer from moral fictions which can only lead to civil unrests and revolutions against the government. He seems to establish the fact that only the political rights, determined by the political superior bear the intelligible meaning and these rights can only realize the happiness of the majority community (Ikegbu \& Diana-Abasi 2017). Rights are to be understood as the fruits of law and law alone that can serve social utility. Any right, therefore, contrary to law so dictated by political superiors should be rejected, refrained and diminished. However, those legal theories also had its vehement critics.

The utilitarian mantra of - greatest happiness of greatest number failed to ensure protection to the minorities against the oppression of the majorities whereas -command of the sovereign concept of positivists only prioritized the need of the few while the rest were to the whims and fancies of the sovereign dictators (Ikegbu \& Diana-Abasi 2017). In the midst of such adversaries revolutions came up and voices roared for human liberty and an international upheaval for restoring the wrongs committed in the past gained quite popularity.

The world community realized that if the concept of right can be generated at an individual level ensuring rights to every individual irrespective of race, colour, nationality and sex the tyranny in the world can be restrained. The minority groups should not fall prey in the hands of superior anarchism and should have their voices to be taken up through recognition of their rights at par with all the members of the community. Thus the idea of human rights developed which were primarily concerned with theorizing various aspects of human relationships: individuals versus individuals, individuals versus the state, and individuals in their relationship with society. In other words, their focus is on the development of individual and social ethics.

The holocaust during the world wars happened to have given ideologies of human rights a universal platform wherein the international community almost unanimously realized the urgent 
need to recognize the value of every human sentiment and entitled every one of them with human rights irrespective of any diversity. The world realized the value of inalienable human rights which can restore peace and integrity in the world and save the future generations from the demonic force of wars. Universal Declaration of Human Rights can be said to have been the first comprehensive document at the international level which created the foundation of new relationship between individuals and global political order followed by other international bill of rights which can claim to be have established a dominant platform for the enforcement of human rights making them more uniform and universalized (Zandy 2019). Human rights developed in the last fifty years can claim to have edged out significant mode of moral justice through moral tropes such as distributive justice, common good and solidarity. However, there are critics to whom such claims to dominance and universality seem to be overstated. As Upendra Baxi has stated that human rights discourse has become commodified, professionalized by technocrats, and sometimes hijacked by powerful groups, so that it is in grave danger of losing touch with the experiences of suffering and the needs of those who should be the main beneficiaries (Baxi 2013). In this regard it can be stated that one needs to understand the corelation between the discourse of justices, human rights and utility. The idea of justice, so far being understood, limits its scope to the understanding of justice as fairness for the sake of flourishing good life to every human being. Thus, the morale of human rights by far being understood is to provide justice to human self with a motive of achieving common good. The utilitarian claim to provide justice focuses on the pains and pleasures of human beings.

On the other hand, when human vulnerability to the environment started causing environmental hazards the concern for environment for the sake of human survival started to come in the forefront. As Cadwell observed, "At the beginning of the twentieth century, neither environment as an integral ecological concept nor the biosphere as the planetary life support system was an object of international concern" (Jones 2011: 76). The common law regime, prevailing in the nineteenth century, failed to protect the environment as the Courts forming the legal opinions hardly could come out of the private economic interests to recognize the global commons. The failure evidenced in the cities and countrysides left scarred by the rapid industrial revolution throughout the common law world. The environmental scars deepened by technological advancement led to the emergence of ecology and environmental law regime which in holistic terms scientifically tried to understand that nature is made up of interdependant evolving components and restoration of such eco-system is therefore significant and thus law regime should promulgate ideas to restore such eco-system.

However, even in the era of 1950 while the concept of human rights was booming at a global level, the problem relating to environment received little attention as a transboundary problem and was restricted to be understood only as local or to some extent regional problem. The concern for environment thus has been at the mercy of domestic regulations. Furthermore, in the post colonial period the idea of development acquired momentum across all the developing continents which resulted in over and unbridled exploitation of natural resources and increasing demand for a better life with new scientific and technological innovations, which consequently resulted in serious risk to human sustenance. This resulted in problems like acid rain, air and water pollution where the problem of the environment started acquiring an 


\section{8| Jurnal Office: Jurnal Pemikiran Ilmiah dan Pendidikan Administrasi Perkantoran \\ Vol. 6, No. 1, January-June 2020, Page 53-70}

international dimension. The extent of damage, actual or potential, to the physical habitat, varied from one segment to the other. However, it cropped up to be a serious overall problem.

Thus looking at the international concern for the environment the global community realized the need to relate the environment with the ideologies of human rights for the sake of human survival both at the present and in the future. In an elaborate understanding on human rights, it must be stated that the conceptualization of human rights ideology happened in three stages. The first generation of rights comprised of civil and political rights and the second generation rights included economic, social and cultural rights. Right to environment interlinked with human rights developed later in the form of third generation of rights along with right to development. However, there are scholars who believe that environmental rights do not neatly fit into any single category or -generation of rights. They can be viewed from all three categories as so mentioned above, straddling all the various categories or generations of human rights. First, environmental concern can be well linked with civil and political rights in a way to give rights to individuals, groups and non- governmental organizations to have access to environmental information in matters concerning environmental law and policy-making. On this view, civil and political rights linked with environment, recognize the empowerment to human beings in participation in environmental decision making and compel the government to meet the minimum standard of protection of life and property from environmental harm. This approach is essentially anthropocentric insofar as it focuses on the harmful impact on individual human beings rather than the environment itself. The civil and political rights recognized as human rights in the arena of environmental policy making and institution building can only lead to protection of human convenience to environment and not environment as an entity in itself (Bassey \& Jr 2019). However, co-relating environment as economic, social and cultural right can be said to have recognized right to descent, healthy and sound environment which States are mandated to achieve progressively.

Thus, according to few scholars, the second categorization of rights in relation to environment comes closer to seeing environment as a good in its own right but, nevertheless one that will always be vulnerable to tradeoffs against other similarly privileged but competing objectives, including right to economic development (Udoudom et al. 2019). Furthermore, even though environment as a right is said to have developed as a third generation of right, however, not many human right lawyers favour the recognition of third generation rights, arguing that they devalue the concept of human rights, and divert attention from the need to implement existing civil, political, economic and social rights fully.

However, in all stages in the development of the environmental law, it has been the institutions that primarily preside over social and economic policies to consider the environmental objectives, thus the environmental priorities have been partial and selective. As a consequence, human rights theory developed to restore nature only to ensure quality human life and human sustenance. Even some critics then were of the view that this concept of human rights theory developed without recognition of human vulnerability to environmental change, and without moral concern for non-human entities, only enabling rights to human beings of enjoying pollution-free environment (Lewis 2018). Thus, the global environment continues to deteriorate, a phenomenon that manifests itself in virtually every sphere featuring interaction 
between man and nature. The full-scale deterioration may not be fully apparent because of the long time lag between the emergence of environmental problems and their recognition. Thus, the scholars in the late eighties have started questioning whether we continue to think about human rights and environment within the existing framework of human rights law in which protection of human rights is the central focal point or the time has come to broaden our thoughts to talk about environmental rights with an aim to transcend from anthropocentrism to eco-centrism.

Commenting on the objective goals which environmental law sought to achieve, it is to be noted that when the concern for the environment came before the global platform, the understanding of the environment and need for its protection were perceived to be strictly human-centric. Thus, amongst other goals which environmental law might have strived to achieve, the prominent one was the "protection of human health, efficiency, national security, preservation for aesthetics or recreation, sustainability, inter-generational equity, community stability, biocentrism, and pursuit of scientific knowledge and technology" (Grachev \& Pliamina 2018: 805).

Environmental law, understood to be a concern for human beings, was converged with the concept of human rights. Considering the inalienability of human rights and environmental law being strictly anthropocentric set up a common goal wherein it was understood that human rights cannot be sacrificed under any circumstances. The international community has effectively adopted the position that environmental law is a method to further the interests of mankind instead of a sacrifice that humans must undertake to protect something greater (Baxi 2016). In addition to this, we do find a plethora of circumstances where environmental law and human rights law converge as there are significant number of objectives in the two realms which are complementary and in many a cases identical. For instance, one major objective of environmental law is the protection of human health (Anton \& Shelton 2011). Furthermore, the debates on sustainable development have increasingly integrated environmental law into human rights.

The sustainable developmental goals are to sustainably use the natural resources so that the future generations of individuals also have the equal opportunity to meet their ends from the natural resources. In addition to it, environmental law's borrowing of ideas from human rights policy is the "right to participate" that is to say, human beings have the right to participate in the decision making process for the sustainable use of the natural resources and they only have the recourse before the adjudicating authorities to take up matters whenever they are directly or indirectly affected by the environmental hazards (Udoudom \& Bassey 2018). Thus, we find that the individual and common objectives of both environmental law and human rights were established. With this, we find that international bodies have made a serious effort to incorporate them in the international law. One such example being the Stockholm Declaration where in Principal 1 it has been stated that " $[\mathrm{m}] \mathrm{an}$ has the fundamental right to freedom, equality and adequate conditions of life, in an environment of a quality that permits a life of dignity and well-being, and he bears a solemn responsibility to protect and improve the environment for present and future generations" (Shelton 2006: 45). With this, it is apparently being made out that man is the fundamental concern and stands in priority than the environment. Even twenty years later with the Rio Declaration also, human rights remained the priority over 


\section{0| Jurnal Office: Jurnal Pemikiran Ilmiah dan Pendidikan Administrasi Perkantoran \\ Vol. 6, No. 1, January-June 2020, Page 53-70}

the environment. In parallel to this, many of the nations have incorporated the right to environment within their constitutional mandate.

However, speaking on the context of environmental law discourse, one needs to take a deeper understanding of the matter of addressing the environmental concern. Human rights and theories of justice have made tall claims to address the environmental concern, however missing on the significant link that environmental justice should not be confined to be understood from the angle of human right to claim environment. Jurists developing environmental literature are only guided by the need to co- relate environmental problems with human sustenance and therefore their actions are strictly anthropocentric which means that the actions so taken by jurists are meant to provide benefits only to human beings. Human rights discourse to address environmental needs is truly anthropocentric on its face; ascribing rights to trees or plants or artefacts is generally acknowledged to be a mere extension; which many feel is analytically dubious.

Rawl's idea of distributive justice as fairness is a virtue of social institutions, meaning human institutions (Ikegbu 2019). Dworkin's basic notion of - equal concern and respect relates to human beings only (Crole2012). Similarly the concern taken for the protection of the future generation is confined for the human sake only. However, it cannot be out rightly denied that the jurists developing the human rights concepts have excluded all the eco-centric morale. Rawls, for example, acknowledges that we have moral duties in respect of animals and nature, but he treats these as falling outside his theory of justice as fairness as a political conception, which only applies to those who have a moral personality. Similarly, Peter Singer has given a different impression in Animal Liberation and held a view that to restrict -rights to human beings and to restrict -utility to sentient beings are not exactly arbitrary though such restrictions do not rule out the possibility of extending the circle of our moral concern to other aspects of nature on the basis of other moral principles (Ojong 2019; Osuala, \& Nyok 2019). Therefore, to him, valuing the environment should be purely anthropocentric, but he leaves the door open for the evolution of a philosophy coherent ecocentric ethos, which according to him is yet to be achieved.

\section{Evolution of International Environmental Law from the Perspective of Human Rights: A Critical Study}

As we discuss the genesis of environmental law-making at a global platform, the concern for environmental protection in conglomeration with human rights first happened in a large platform of the international arena when the developing nations took the initiative to come forward with Stockholm Declaration in 1972 (Gray 1990). However, first treaties relevant to environmental protection can be found much earlier in the form of mostly bilateral treaties or agreements concerning fisheries, problems of the equitable utilization of water resources by riparian states or the protection of the wildlife birds which date from the late nineteenth century.

Reference can be drawn of a Convention on Protection of Birds useful for agriculture which was entered in 1902. During the period of the late nineteenth and early twentieth centuries, we find pieces of evidence where the elite in Europe and North America established 
national nature conservation organizations which lobbied for the conclusion of treaties and nature conservation (Herman 2015). However, despite of a number of Conventions and treaties entered into during the tenure till 1972, none of them can be considered to have significantly contributed to systematic development of right to environment as a human right or environmental right. They all lacked the instrumentality to develop a general framework on environmental law. Prior to 1940 international environmental concern was strictly restricted to protection of few species which were considered to be valuable resources to humans or to protection of human health (Herman 2015). Even the period between 1940 and 1972 the motivation derived for development of international environmental law was only to protect valuable components in terms of human needs. The UN Charter of 1945, which is considered to the founding father for the recognition of human rights, made neither environmental protection nor the conservation of the natural resources the explicit task of the United Nations.

However, inspite of the silence of the UN Charter on ecological matters, soon addressed questions of international environmental protection in particular concerning to the conservation of natural resources which might come into conflict with resource utilization came to the forefront (Mizuno 2017). Special mention should be made in this respect of the UN Conference on the Conservation and Utilization of Resources, 1949, convened by the Economic and Social Council, where the interrelation of the utilization and conservation of resources was exhaustively discussed for the first time (Mizuno 2017). It is exactly this tension between the competing regulatory aims of resource utilization and conservation that is symptomatic of the subsequent international agreements dealing with the law of the sea and the law of fresh water resources. In the 1950s, states made initial sporadic attempts to regulate by treaty certain aspects of the protection of environment, specially the marine resources. The Convention on Fisheries and Conservation of Living Resources of the High Seas, 1958 concluded during the UN Conference on the Law of the Sea in Geneva as well as few regional arrangements can be stated as those sporadic attempts (Tsioumani 2019). It was towards the end of the sixties era, the awareness to understand the implication of environmental degradation came in the forefront due to public awareness and global pressure, especially from the developing nations. It was then the focus was laid to recognize right to environment for the sake of human sustenance in a more holistic manner (Bassey 2019).

The scholars (Sand 2012; Tolba 2019) narrating on the historical evolution of environmental law generally distinguish the evolution happening in three major phases, viz.

- The -traditional era preceding the Stockholm Declaration, 1972

- The formative-modern era i.e. post Stockholm to 1992 United Nations Conference on Environment and Development, Rio de Jenerio; and

- The -post-modern erall from Rio onwards,

The traditional law started with the natural resource management mission through bilateral and regional agreements between states and dispute settlement arrangements over the shared utilization of water resources, wildlife and fisheries in transboundary areas and over the allocation and exploitation of 'fugitive' marine resources in areas outside national jurisdiction. However, in spite of few fragmented areas being identified in the protection of environmental law, traditional era lacked a comprehensive framework to develop environmental law in a broader scale (Tolba 2019). Furthermore, the efforts to inculcate ethical ideas in the 


\section{$62 \mid$ Jurnal Office: Jurnal Pemikiran Ilmiah dan Pendidikan Administrasi Perkantoran \\ Vol. 6, No. 1, January-June 2020, Page 53-70}

environmental law-making had not been in focus. The impact of air pollution, transboundary movement of the hazardous wastes or burning issues of global warming or climate change were not even been perceived during that time.

Moreover, prior to Stockholm era, the concern for attaching human rights perspective to environmental protection was far from being recognized as environmental treaty making was clearly dominated by the industrialized states where only close relation between natural conservation and colonialism could be traced with no hindrance of social or economic goals of underdeveloped countries. Therefore, in the Stockholm Conference, where developing states got a platform to speak out their own concern pursued a new conceptual approach by stating that environmental protection should be an integral part of developmental measure and vice versa. However, many of the developing countries did not buy this idea and clearly resisted this pragmatic shift in environmental and developmental thinking stating that pollution of the environment was primarily the result of industrialization and therefore should be a concern for the developed countries. Consequently, in the post Stockholm era, 1974, the developing states, organized in the Group of 77 and succeeded in the efforts to make the UN General Assembly adopt the Declaration on the Establishment of a New Economic Order as well as the Charter of Economic Rights and Duties of States which were inspired by the idea of overcoming the injustices in the then existing international legal system (Annabi \& Jalali 2018). This resulted in the liberalization of the global market for the developing countries, acknowledging full and permanent sovereignty of the own country's natural resources, facilitating the access of the developing countries to modern technology and enhancing their infrastructure so on and so forth. Thus we find that though the Stockholm Declaration aimed at establishing a new legal regime of understanding environmental ethics yet it gave impetus to the north-south conflict which many scholars understand as -environmental rascism (Xi 2000). In the post Stockholm era, that is in the modern era, the spectrum of environmental law pervaded the national and regional boundaries and acquired an international platform going beyond the stereotype of -transboundary matters on the one hand and 'governance of commons' on the other, to match not only the growing environmental agenda of regional regimes, but also the growing catalogue of environmental problems that had once seemed local, yet turned out to be globally shared (O'Doherty 2017). The international community at the United Nations Conference held at Stockholm declared that -man has the fundamental right to freedom, equality and adequate conditions of life, in an environment of a quality that permits a life of dignity and well-being, and he bears a solemn responsibility to protect and improve the environment for the present and future generations (Xi 2000).

This grand statement might have provided the basis for subsequent elaboration of a human right to environmental quality, yet its real-world impact has been noticeably modest. Fetching further, the Rio Declaration of 1992 makes human beings the -central concern of sustainable development and refers only their being entitled to a healthy and productive life in harmony with nature (Xi 2000). Thus, Rio Declaration failed to give greater emphasis to human rights was indicative of uncertainty and debate about the proper place of human rights law in the development of international environmental law. However, in the post modern era, where the international, state as well as the non-state actors try to broadly and deep rootedly 
conceptualize the concepts of precautionary principle, polluter-pays principle, sustainable development, public trust doctrine with an intent to safeguard human rights, they have been largely disturbed with the alarming increase of -treaty congestion (Ogar 2019).

Thus, in this era the actors instead of working more on evolving new principles in the protection of environment laid more focus on to achieve new legal polycentricity (Tsioumani 2019) breaking through the traditional egalitarian fictions by acknowledging the concept of -common but differentiated responsibilities. It confirmed that differential treatments to developing countries are required considering their special social and economic circumstances. Thus, the issues like climate change and biodiversity promoted a new trend of shouldering more responsibilities upon the developing countries owing to the fact that they are the major polluters of the environment and therefore more responsibilities to be borne by them to achieve the goal of pollution free environment.

Therefore, environmental governance, a process that developed to cater the need for institutional building for policy development on one hand and follow-up mechanism on the other, got struck in the dichotomy to effectively address harmoniously to both developed and developing countries. However, the recent Paris Agreement, which was adopted in $21^{\text {st }} \mathrm{COP}$ of UNFCCC aims to achieve climate mitigation, adaptation and finance through a series of cooperative frameworks and mechanisms, each of which establishes different legal rights and obligations for Parties, and explicitly makes provision for the needs of developing country Parties, especially the most vulnerable. However, the efforts put forward have to pass the test of the time to prove its worth (Sand 2012).

However, the postmodern environmental legal era also brought about the participatory revolution establishing the legitimate claim of the civil society to take part in the environmental protection. The institutions like Bank Inspection Panel established in 1993, the Commission on Environmental Cooperation established in 1994 under the North American Free Trade Agreement, Compliance Committee established in 2002 under the Aarhus Convention on Access to Information, Public Participation in Decision-Making and Access to Justice in Environmental Matters have been admitted as non-state actors which recognize the legitimate right of the human beings to take part in international decision makings (Coyle 2017).

\section{Human Right to Environment as a Constitutional Right}

In view of the international initiatives to make environment a human concern, most domestic legal regime trying to give shape to protect the environment ought for constitutionalisation of the rights with direction given upon states to protect environment in the light of right of its people to enjoy such right. The key reasons for such constitutionalisation can be attributed to a number of factors. Constitutionalisation of rights ensures fundamental claim for protection of those rights by State machinery (The Constitutionalisation of International Law 2014). It is an individual's claim for ensuring the rights separable from the concept that rights emanate from the dictate of the sovereign. Therefore, constitutionalisation of environmental rights brings out individualistic and libertarian characteristic which predominately seeks to bring out revolutionary ideas to protect human beings from all form of environment related hazards. Right to environment as a constitutional right claims to encourage greater civic 


\section{4| Jurnal Office: Jurnal Pemikiran Ilmiah dan Pendidikan Administrasi Perkantoran Vol. 6, No. 1, January-June 2020, Page 53-70}

involvement in environmental concerns. It is considered to be a synthesis right (Marrani 2008) as it embodies specific characteristics distinguishable from other form of rights. This right to environment cannot be categorically stated to belong to civil, political or social or for that matter economic right, but can be considered to be a right which needs an intervention from all civil, political, social and economic arenas to refrain from harmful activities to the environment for the survival and sustenance of mankind.

The right to environment was recognized as a right to a healthy or clean environment or an environment conducive to well-being and higher standards of living. Some bolder formulations speak of a right to a decent environment encompassing social and cultural aspects that take, for example, into account the suitability of a given environment to an individual or a people according to its social and cultural needs and thus acknowledge the interdependence of all elements of the human environment. Since then major environmental concerns that followed in the realm of international environmental law were for restoration the natural resources, prevention from pollution caused by various means, climate change conditions and so on. The concepts of precautionary principle, polluter-pays principle, and sustainable development came in the forefront, all which intended to safeguard human rights (Sustainable Development Commission 2007). In a dichotomy between economic development and protection of environment, it was argued that development, in all its manifestations, is an end to be achieved through the means of human right to environment. Thus, it is understood that international environmental law and human rights law have intertwined objectives which aim at striving for better conditions of life on earth. The two discourses together seek to tackle universal challenges that must often be solved at the same time from for the purpose of the human survival. There is an utmost necessity to interlink between environment and human rights so as to establish claim for right to environment.

Therefore environmental law on the line of human rights law seeks to safeguard the benefit of humankind both on a local and global scale (Sumudu \& Andrea 2019). Human rights have centered on fundamental aspirations of human beings with much more developed compliance mechanisms allowing individuals and groups to claim their rights. The inclusion of an environmental dimension in the human rights regime has become necessary in view of the recognition of the pervasive influence of local and global environmental conditions upon the recognition and realization of human rights. In legal terms, the linkages will to enhance the protection in both fields as the protection of the environment will benefit from the established machinery whereas the human rights system will be enhanced by the inclusion of new interpretative elements until recently ignored (Sumudu \& Andrea 2019).

\section{Human Right or Environmental Right?}

A co-relation inevitably is drawn between right to environment and right to life. Some scholastic view also claims that there is no reason to recognise right to environment as a separate human right as the basic human rights especially right to life already protects individual 
Kemi Anthony Emina; Overview of Environmental Jurisprudence within Environmental Ethics 65

from environmental harm (Sumudu \& Andrea 2019). However, such a proposition has not weakened the argument of right to environment as a specific constitutional right.

However, how far human rights perspectives offer a viable contribution in encountering environmental degradation is a highly contentious aspect of the environmental debate (Marrani 2008). This regime of environmental law conceptualized in the form of right to environment is interestingly being termed as a pure -anthropocentric concept which clashes with the philosophical idea of -ecological rights. Ecological rights as is denoted to be the ecocentric approach to environmental law-making seeks to recognize the intrinsic value of nature and thereby prescribe for rights to be entrusted to it as well.

The pragmatists add value not only to the human beings, but also other animals and species, flora and fauna, all of which as a whole compose the mother earth. The chief exponents of this philosophy are Aldo Leopard, J. Baird Callicott and Laura Westra according to whom environmental sentiments incompatible with the sentiments of human beings should be looked into while developing environmental jurisprudence. (Culp 2013). This philosophy is termed as eco-centrism wherein the environment in all its manifestation is considered to be the subject of right. The commendable work of Aldo Leopard on Land Ethics in 1949 viewed that a thing in its origin has the tendency of being inter-dependant individuals or groups to evolve modes of co-operation which the ecologists term as symbiosis (Culp 2013).

Therefore all ethics so far which has evolved rest upon the idea of inter- dependant community concept and this community in its enlarged version includes not only the human race but also goes on to include soil, water, plants and animals, whom we can collectively refer to as land (Bassey 2019). Each component of the environment though instincts to compete with each other in its struggle for existence, yet each of them has some dependency on other components which prompts it to co-operate. However, in the early 1980s the issue of attaching rights to the nature became a matter to be debated among the environmental philosophers and therefore the concept of right and right-based values, in the legal regime, have been examined and interpreted through various angles by the jurists. The environmentalist for developing the concept of rights challenged the pre-eminent role of instrumental value arguments, and developed philosophy in support of environmental concerns and arguments and therefore turned to an examination of non-instrumental or intrinsic value arguments for the preservation of the nature.

The term intrinsic value denotes a thing which is intrinsically valuable or in other term, bears an inert value (Griffiths et al 2016). Therefore in order to attach rights to the objects having intrinsic value, the ethicists-cum-environmentalists started to look into the elements of non-anthropocentric intrinsic values which is supposed to be independent of and override individual human judgment and evolve cultural ideals, which currently supports the preservation of the natural environment. This objectivist vision for valuing environment was propounded by jurists like Holmes Rolston III and Paul Taylor according to whom class of entities having inherent worth is extensionally equivalent to the class of living beings (Griffiths et al 2016). Thus, nonliving objects can only be defended on the grounds that they are instrumentally valuable to living centers of purpose that use them for their own intrinsically valuable ends and therefore are conferred with the right to be protected and preserved. 


\section{Jurnal Office: Jurnal Pemikiran Ilmiah dan Pendidikan Administrasi Perkantoran}

Vol. 6, No. 1, January-June 2020, Page 53-70

However, the 1982 World Charter for Nature was the first international document which introduced eco-centrism in the realm of international environmental law. Its preamble expresses some distinctly eco-centric thinking, referring to mankind as part of nature, to civilization as rooted in nature, to every form of life being unique and meriting respect regardless of its worth to man, and to the need for man to be guided by a code of moral action (Bassey 2019). It further declares that nature shall be respected, and it the humans who should bear the responsibility to recognize the rights of nature and restore them, since they are responsible for exhausting the nature and its resources.

The Charter however is only declaratory and not legally binding. But in the opinion of commentators on international environmental law, Charter principles "indicate the prevailing concepts and direction of international environmental law" (Singh 1977: 26). Furthermore, Charter principles have been incorporated into some important international conventions, such as the 1985 ASEAN Agreement on the Conservation of Nature and Natural Resources. Other international treaties which take into account the intrinsic value of the environment (including ecosystems and species) include the 1980 Convention for the Conservation of Antarctic Living Resources, the 1991 Protocol to the Antarctic Treaty on Environmental Protection, the Berne Convention on the Conservation of European Wildlife and Natural Habitats and the CITES Convention.

In comparison, the declarations and treaties negotiated as part of the 1992. The preamble of the Convention on Biological Diversity, also recognizes the intrinsic value of the biologically diverse nature resources as it opens with the words: "Conscious of the intrinsic value of biological diversity and of the ecological, genetic, social, economic, scientific, educational, cultural, recreational and aesthetic values of biological diversity and its components.." (Ciment 2015: 683). Intrinsic values find further expression in this Convention, in the context of identifying components of biological diversity requiring conservation. Values beyond those of human utility are identified as being significant. Furthermore, Article 2 of the draft IUCN World Conservation Union International Covenant on Environment and Development states as a fundamental principle "Nature as a whole warrants respect; every form of life is unique and is to be safeguarded independent of its value to humanity" (Scanlon 2005: 2556).

\section{CONCLUSION}

In spite of fragmented attempts made in the international regime for adding ecocentric values in the environmental law-making, the pace has been extremely slow and unsystematic. Environmental jurisprudence till date has been continuing with anthropocentric ideas with all concerns for safeguarding the means of human survival. Even the eco-centric concerns raised so far do not categorically confer right to the environment but only reflects about human liability to conserve its intrinsic value. As Christopher Stone rightly pointed out, each time there is a movement to confer right to some new entity it becomes an issue of revolution. The reason being, human beings by nature are reluctant to issue rights to those objects over which it can exercise its rights. Throughout the evolution of the history of law there have been shifts in a 
cluster of related property variables, such as what things to be considered to be owned, who bear the legal rights to own, powers and privileges of ownership and so on. The changes brought a change in the consciousness of viewing things. The question is complicated because the law tends to protect all sorts of things, but not in a manner that would lead us to say that these things are the owner of the rights. For example, clean environment is not a -right because human species can control environment in a large extent, but it is a right because human beings also form a part of the ecology.

\section{REFERENCES}

Akpan, B. S., \& Leonard, N. (2018). Environmental ethics: from philosophy to movement. Bulletin Social-Economic and Humanitarian Research, (2).

Annabi, A. R., \& Jalali, M. (2018). Study the evolution of international environmental. Amazonia Investiga, 7(13), 72-81. Retrieved from https://www.amazoniainvestiga.info/index.php/amazonia/article/view/496

Anton, D. K., \& Shelton, D. L. (2011). Environmental protection and human rights. Environmental Protection and Human Rights (Vol. 9780521766388). doi:10.1017/CBO9780511974571

Bassey, S. A. (2019). 'Anthropoholism'As an Authentic Tool for Environmental Management. International Journal of Environmental Pollution and Environmental Modelling, 160-168.

Bassey, S. A., \& Jr, T. M. P. (2019). Enyimba's Notion of Madukaku and The Question of Anthropocentricism In African Environmental Ethics. Int. J. of Environmental Pollution \&Environmental Modelling, 2(3), 129-136.

Baxi, U. (2016). Towards a climate change justice theory? Journal of Human Rights and the Environment, 7(1), 7-31. doi:10.4337/jhre.2016.01.01

Baxi, Upendra: The Future of Human Rights. (2013). Časopis pro Právní Vědu a Praxi, 21(4), $552-553$

Burger, M. (2013). Environmental law/environmental literature. Ecology Law Quarterly, 40(1), 1-57. doi:10.15779/Z386G42

Ciment, J. (2015). Social Issues in America: An Encyclopedia. Social Issues in America: An Encyclopedia. doi:10.4324/9781315700724

Coyle, S. (2017). Natural Law in Aquinas and Suarez. Jurisprudence, 8(2), 319-341. doi: $10.1080 / 20403313.2017 .1324057$

Crole, R. L. (2012). Alpha equivalence equalities. Theoretical Computer Science, 433, 1-19. doi:10.1016/j.tcs.2012.01.030

Culp, H. (2013). Land Ethic Under Attack: Keystone XL and the War Over Domestic S(OIL). Environmental and Earth Law Journal (EELJ). Retrieved from http://lawpublications.barry.edu/ejejj/vol3/iss1/4

Duke, E. O. (2020). From Christian spirituality to eco-friendliness. International Journal of Humanities and Innovation (IJHI), 3(1), 34-38. 
68| Jurnal Office: Jurnal Pemikiran Ilmiah dan Pendidikan Administrasi Perkantoran Vol. 6, No. 1, January-June 2020, Page 53-70

Eyo, U. E. . (2019). Between Religion and Agriculture: A Roadmap to Revamping Nigeria's Economy . GNOSI: An Interdisciplinary Journal of Human Theory and Praxis, 2(1), 6270.

Faye, J. (2016). Hermeneutics and Human Nature. Journal of Literary Theory, 10(1). doi:10.1515/jlt-2016-0002

Grachev, V., \& Pliamina, O. (2018). Industrial and environmental safety in the integrated security policy of the industry, a corporation and an enterprise. International Journal of Mechanical Engineering and Technology, 9(7), 802-812.

Gray, M. A. (1990). The United Nations Environment Programme: An assessment. Environmental Law, 20(2), 290-319.

Griffiths, M. R., Lucas, J. R., Griffiths, M. R., \& Lucas, J. R. (2016). Economic Value and Intrinsic Value. In Value Economics (pp. 143-174). doi:10.1057/978-1-137-54187-1_8

Herman, O. (2015). The international convention for the protection of birds concluded in 1902; and Hungary. Historical sketch. The international convention for the protection of birds concluded in 1902; and Hungary. Historical sketch. doi:10.5962/bhl.title.105126

Ikegbu, E. A., \& Diana-Abasi, F. I. (2017). Utilitarianism as a Veritable Vehicle for the Promotion of a Just Society. Lwati: A Journal of Contemporary Research, 14(2), 121137.

Ikegbu, E. A., Ogar, J. N., \& Inyang, J. O. (2009). Nigeria's ethnic diversity and its proneness to conflict and violence. Ndunode: Calabar Journals of the Humanities, 8, 109-182.

Ikegbu, E. A., Solomon Kingsley, C., \& Sunday, A. D. (2013). Leadership and Good Governance: Roadmap to Moral and Economic Recovery in Africa. American Journal of Social Issues and Humanities, 3(1), 43-52.

Jones, K. (2011). Writing the wolf: Canine tales and North American environmental-literary tradition. Environment and History. doi:10.3197/096734011X12997574042964

Lewis, B. (2018). Environmental Human Rights and Climate Change. Environmental Human Rights and Climate Change. doi:10.1007/978-981-13-1960-0

Marrani, D. (2008). The Second Anniversary of the Constitutionalisation of the French Charter for the Environment: Constitutional and Environmental Implications. Environmental Law Review, 10(1), 9-27. doi:10.1350/enlr.2008.10.1.002

Mendie, P. J., \& Eyo, E. (2016). Environmental Challenges And Axiology: Towards A Complementary Studies In Eco-Philosophy. Journal of Integrative Humanism, 7(1), 144150.

Menell, P. S. (2019). Environmental law. Environmental Law. doi:10.4324/9781315194288

Mizuno, S. (2017). Global Governance of Natural Resources and the British Empire: A Study on the United Nations Scientific Conference on the Conservation and Utilization of Resources, 1949 (pp. 291-308). doi:10.1007/978-3-319-41139-2_16

Njar, B. I., \& Enagu, D. A. (2019). Development and Environmental Sustainability in Nigeria: An African Perspective . GNOSI: An Interdisciplinary Journal of Human Theory and Praxis, 2(1), 37-47. 
Kemi Anthony Emina; Overview of Environmental Jurisprudence within Environmental Ethics 69

O'Doherty, S. (2017). Environmental human rights - concepts of responsibility. In Environmental Human Rights: A Political Theory Perspective (pp. 149-166). doi: $10.4324 / 9781315188249$

Ogar, J. N. (2019). Ethical Implication of Environmental Crises on African Societies: A Challenge to Future Humanity. International Journal of Environmental Pollution and Environmental Modelling, 109-115.

Ogar, J. N., \& Bassey, S. A. (2019). African Environmental Ethics. RAIS Journal for Social Sciences, 3(1), 71-81.

Ojong, L. O. (2019). Singer's Notion Of Speciesism: A Case For Animal Rights In Ejagham Culture. International Journal of Environmental Pollution and Environmental Modelling, 116-121.

Osuala, A. N. ., \& Nyok, E.-I. E. (2019). New Twist to Political Corruption in 4th Republic Nigeria given Non- Human Animals Stealing millions: A Case for the Defense of Animal Rights. GNOSI: An Interdisciplinary Journal of Human Theory and Praxis, 1(2), 15-37.

Sand, P. H. (2012). The Evolution of International Environmental Law. In The Oxford Handbook of International Environmental Law. doi:10.1093/oxfordhb/9780199552153.013.0002

Scanlon, J. (2005). International issues for energy for sustainable development: IUCN perspectives. In The Law of Energy for Sustainable Development (pp. 255-259). doi:10.1017/CBO9780511511387.019

Shelton, D. (2006). Human Rights and the Environment: What Specific Environmental Rights Have Been Recognized? Denver Journal of International Law and Policy, 35(1), 129.

Singh, N. (1977). A world charter for nature. Environmental Policy and Law, 3(1), 24-26. doi:10.1016/s0378-777x(77)80057-7

Sustainable Development Commission. (2007). The natural environment, health and well-being. Healthy Futures \#6, 1-4.

The Constitutionalisation of International Law. (2014). In The Democratic Legitimacy of International Law. doi:10.5040/9781472565129.ch-004

Tolba, M. K. (2019). The Evolution of International Environmental Law. In Global Environmental Diplomacy. doi:10.7551/mitpress/3293.003.0005

Tsioumani, E. (2019). The 2018 un Biodiversity Conference. In Environmental Policy and Law (Vol. 49, pp. 19-24). doi:10.3233/EPL-190117

Udoudom, M. D., \& Bassey, S. A. (2018). Plato and John Rawls on Social Justice. Researchers World, 9(3), 110.

Udoudom, M. D., Okpe, O., Adie, T., \& Bassey, S. A. (2019). Environmental Ethics. Budapest International Research and Critics Institute (BIRCI-Journal): Humanities and Social Sciences, 2(2), 48-55.

United Kingdom Environmental Law Association. (2014). Climate Change - Law Search. Law \& Your Environment: The plain guide to environmental law. Retrieved from http://www.environmentlaw.org.uk/rte.asp?id=54

Xi, W. (2000). Implementing the rio declaration and agenda 21 in China. Asia Pacific Journal of Environmental Law. 
70| Jurnal Office: Jurnal Pemikiran Ilmiah dan Pendidikan Administrasi Perkantoran Vol. 6, No. 1, January-June 2020, Page 53-70

Zandy, J. (2019). Universal declaration of human rights. Radical Teacher, 113, 54-55. doi:10.5195/rt.2019.591 